\title{
Factors Affecting the Elderly in Performing Social Services: A Case Study on the Elderly not Possessing a Volunteer Card
}

\author{
Kuo-Yu Peng ${ }^{1 *}$ and Hsiu-Li Liao ${ }^{2}$
}

\begin{abstract}
The objective of this study is to discuss among those over 65 years old who do not have a volunteer card and are not registered with the local social service bureaus in Taiwan the motivational factors affecting their participation in social services. This study constructs its subject from the theory of motivation, with the aim to understand the satisfaction level of the elderly in social participation. The research findings are: (1) The will of an individual and the ability the person possesses can perpetuate the value of their social existence; (2) Influenced by fate and opportunity, the elderly are motivated to devote effort to search for social balance and regain a focus and role in life that will give them satisfaction; (3) The elderly enjoy serving the community by quietly doing good deeds and making private donations; (4) For the elderly overwhelmed by the fear of the unknown after retirement, their sense of loss changes after adapting to social services and interpersonal relationships; and (5) The elderly enjoy being able to seamlessly connect and find the beginning to another beautiful stage of life. These findings will provide references for social servicerelated practices for the elderly and follow-up studies.
\end{abstract}

JEL classification numbers: L31, J14, J32.

Keywords: Social service, Elderly, Participation motivation.

\footnotetext{
${ }^{1}$ Ph.D. Program in Business, College of Business, Chung Yuan Christian University, Taoyuan City, Taiwan.

2 Department of Information Management, College of Business, Chung Yuan Christian University, Taoyuan City, Taiwan.
} 


\section{Introduction}

\subsection{Research Background}

The problem of the aging population in Taiwan is no longer news. In 2018, Taiwan officially became an aging society (with elderly people accounting for over $14 \%$ of the total population); by the end of June 2021, there were approximately 3.86 million people over the age of 65 [1]. The continued aging of the population will undoubtedly bring significant challenges to society in Taiwan, with a direct impact on families, the relationship between people, the social welfare system, the labor market, and industrial development. On the contrary, the increase in the elderly population also brings different opportunities to society, including the growth of senior human resources and the development of industries and technologies related to services for the elderly.

Social service implies an engagement that is not forcibly solicited but rather an activity that people choose to participate in. It is all about one's intention, as it is neither subsidized nor paid; it is about giving rather than receiving. With regard to the participation of the elderly in social services, Chambré found in a study of senior citizens in the United States that changes in life of the elderly helped them live longer and healthier and retire earlier [2]. Government policies, the main contributor toward this phenomenon, encouraged American seniors to be more inclined to participate in voluntary social services due to the country's more comprehensive elderly welfare policies, which motivate seniors to actively serve. With regard to encouraging social services for the elderly, Atchley argues that retirement is the beginning of life for an elderly person and a turning point in their life [3]. It represents the end of their original job and the start of a new life. The elderly make the effort to keep working after retirement to reaffirm the value of their life, which not only helps in continuous lifelong learning and self-development but also allows them to contribute to society and achieve new glories in their retirement life. Turner argued that elderly people can increase their self-affirmation and spiritual satisfaction by assisting others through social services, which is a service-based aspiration and enthusiasm [4].

The subject of this study is the elderly who do not have a volunteer card. The main difference between them and the elderly who have a volunteer card is that the latter can enjoy some benefits (trips and rebates), while those without the card do not receive any rewards for the services they provide but have more freedom and flexibility. This study explores whether not having a volunteer card has a positive and effective impact on the daily lives of elderly people, including their community and religious activities. According to Mitchell et al., the most frequently cited research in literature on management behavior and motivation is in two areas [5]. One is task-driven, rational, scientific management behaviors that are driven by "their own" motivations. The other is a participatory, interpersonal approach, which refers to the philosophy of "caring for others." Townsend stated that social services for the elderly have been proven to improve the health, well-being, and quality of life of the elderly [6]. Therefore, it is hoped that the implications derived from the 
interviews in this study and the theories cited can be used as a reference for future elderly welfare service providers and aging population-related workers..

\subsection{Research Motivation and Objective}

In the field of social services, the issue of "What are the retired elderly doing?" has always been an area of interest to the researcher, which may be due to their past work background. The researcher worked as a judicial police officer, and as he was relatively young, the majority of people he worked with were seniors who were nearly 65 years old and about to retire. Most of the residents in his area of responsibility were senior citizens, and there were few people of the same age as the researcher. As a result, the researcher interacted more naturally and comfortably with the elderly than with those from other age groups.

However, in response to the current situation of an aging society, the researcher changed his job to a general administrator. When visiting these retired elderly during his holidays, he observed that these elderly people engaged in "social services" after retirement. The main reason for their involvement was that they were very "active" in their previous lives as police officers and enjoyed being in contact with people. Certainly, there were a few of them who did not engage in social services due to their physical conditions and chose to stay at home and not be disturbed by others. When the researcher observed these phenomena, he started thinking about the reasons that caused these elderly to be involved in social services. Is it a preference for the activities in social services? Or are there other factors?

\subsection{Research Questions}

By exploring the considerations and benefits of social services for the elderly, this study hopes to understand the reasons for their continued participation in social services and to identify ways to enhance their participation.

The research questions that we would like to discuss are as follows:

a. What is the relationship between the personal background of the elderly and their considerations for social services and the benefits received?

b. What are the motivations and difficulties of the elderly in social services?

c. What are the changes for the elderly before and after they engage in social services?

\section{Literature Discussion}

This chapter consists of two sections and is aimed at exploring the relevant factors that influence the elderly to undertake social services. The first section is about the connotation of the participation of the elderly in social services and related studies, while the second section is about the motivation of the elderly to participate in social services and related theories. Each section is divided as follows. 


\subsection{Connotation of the Participation of the Elderly in Social Services and Related Studies}

\subsubsection{The Elderly Population}

The World Health Organization (WHO) defines senior citizens as those over 60 years of age. However, this study is based on the definition of Article 2 of Taiwan's Senior Citizens Welfare Act, which refers to elderly as people who are 65 years old and above. The Law of the People's Republic of China on the Protection of the Rights and Interests of the Elderly stipulates that "the elderly" refers to citizens who are at or above the age of 60. The World Report on Ageing and Health published by WHO in 2016 defines an old person as a person whose age has passed their median life expectancy at birth. The report does not define the elderly by a specific age and holds the attitude that age should not be used to define the elderly.

\subsubsection{Social Services}

Social services aim to improve the social environment and enhance the social functions and relationships between individuals, others, and the environment. It is a systematic and organized activity that is also a social welfare measure and a way of promoting social work. The range of services is very wide, and there are different classifications according to the theme, goal, target, region, and nature of the service. Yu-yuan Chen defines social participation as an individual's participation in social activities by incorporating their own subjective ideas, thoughts, and actions; demonstrating active participation in social operations; and sharing resources with members of society to promote positive interactions, with the objective of enhancing self-growth and improving interpersonal relationships, social relationships, and quality of life [7]. Shun-Fen Tzeng argues that for the elderly, social participation is about contributing to the society with their abundant wisdom, experience, and ability and enjoying the right to participate [8,9]. Improving the level of life services for the elderly can lead to their participation in public welfare activities, awareness of government affairs, and participation therein and can increase their satisfaction with social services. Kai discovered that participation in social activities by the elderly has a significant positive effect on their cognitive function [10]. Studies related to the elderly and social services are shown in Table 1. 
Table 1. Studies Related to the Elderly and Social Services

\begin{tabular}{|c|c|c|}
\hline Scholar/Year & Title & Research Results \\
\hline Kai Sun [10] & $\begin{array}{c}\text { Understanding the impacts of } \\
\text { Internet use on senior Citizens' } \\
\text { social participation in China: } \\
\text { Evidence from longitudinal panel } \\
\text { data }\end{array}$ & $\begin{array}{l}\text { Frequent use of the Internet can lead to } \\
\text { reduced social participation among senior } \\
\text { citizens. Its frequency of use can result in the } \\
\text { following: } \\
\text { (1) social participation of elderly with higher } \\
\text { cognitive function } \\
\text { (2) seniors who receive pension participate in } \\
\text { fewer social activities } \\
\text { (3) social participation of female seniors is the } \\
\text { lowest. }\end{array}$ \\
\hline $\begin{array}{c}\text { Yinan Zhang } \\
\text { [11] }\end{array}$ & $\begin{array}{c}\text { Design of Elderly Care Service in } \\
\text { Rural Community with Mutual } \\
\text { Assistance Mode-A Case Study } \\
\text { of B Rural Community in A } \\
\text { Town, Beijing }\end{array}$ & $\begin{array}{l}\text { Stimulate the inner vitality of the elderly in } \\
\text { rural communities through their mutual } \\
\text { assistance and spontaneous participation in } \\
\text { community activities. In the senior citizen } \\
\text { resource service system, the elderly are } \\
\text { transformed from service providers to } \\
\text { participants and service contributors. It is } \\
\text { hoped that the elderly can realize their self- } \\
\text { worth and enhance their sense of well-being. }\end{array}$ \\
\hline $\begin{array}{c}\text { Ausanee } \\
\text { Wanchai [12] }\end{array}$ & $\begin{array}{c}\text { Social participation types and } \\
\text { benefits on health outcomes for } \\
\text { elder people: A systematic } \\
\text { review }\end{array}$ & $\begin{array}{l}\text { The social participation models of the elderly } \\
\text { can be divided into two models: (1) collective } \\
\text { participation and (2) productive participation. } \\
\text { Both the social participation models can } \\
\text { improve psychosocial problems in seniors. } \\
\text { The author suggests that to successfully } \\
\text { promote healthy aging for these individuals, } \\
\text { health care providers should encourage the } \\
\text { elderly to engage in social activities. } \\
\text { However, more rigorous research is required } \\
\text { to confirm the association between the types } \\
\text { of social engagements and health benefits for } \\
\text { these elderly. }\end{array}$ \\
\hline $\begin{array}{c}\text { Guiqing Zhang } \\
{[13]}\end{array}$ & $\begin{array}{l}\text { A Study on the Correlations } \\
\text { among Elder Volunteers' } \\
\text { Participation Motivation, } \\
\text { Happiness, and Intention of } \\
\text { Continuous Participation }\end{array}$ & $\begin{array}{l}\text { The study proves that "participation } \\
\text { motivation," "happiness," and "intention of } \\
\text { continuous participation" have positive } \\
\text { correlations. Based on the results of the study, } \\
\text { recommendations are made to improve the } \\
\text { efficiency of the organization's services } \\
\text { through changes in these three influencing } \\
\text { factors under the current manpower shortage } \\
\text { context in society. }\end{array}$ \\
\hline Meifen Li [14] & $\begin{array}{l}\text { A Study on the Relationship } \\
\text { Between Participation Attitudes } \\
\text { and Self-Efficacy of Senior } \\
\text { Volunteers }\end{array}$ & $\begin{array}{l}\text { 1. Senior volunteers have highly positive } \\
\text { attitudes toward participation and perform } \\
\text { best in the "participation perception" } \\
\text { dimension and slightly weaker in the }\end{array}$ \\
\hline
\end{tabular}




\begin{tabular}{|c|c|c|}
\hline & & $\begin{array}{l}\text { "ability to participate" dimension. } \\
\text { 2. The performance of senior volunteers was } \\
\text { highest in the "interpersonal integration" } \\
\text { dimension and slightly lower in the } \\
\text { "ability in work practice" dimension. } \\
\text { 3. Female senior volunteers have a more } \\
\text { positive attitude toward participation than } \\
\text { male senior volunteers. } \\
\text { 4. Female senior volunteers performed better } \\
\text { than male senior volunteers in } \\
\text { interpersonal integration. } \\
\text { 5. The more positive the participation } \\
\text { attitude of senior volunteers is, the higher } \\
\text { the self-efficacy performance is. }\end{array}$ \\
\hline $\begin{array}{c}\text { Hui Hui Lee } \\
{[15]}\end{array}$ & $\begin{array}{l}\text { Discussion on experiential } \\
\text { learning and reflexivity practice } \\
\text { for middle and old age } \\
\text { counseling volunteers-with } \\
\text { Keelung Lifeline as case study }\end{array}$ & $\begin{array}{l}\text { 1. There is no causal correlation between the } \\
\text { motivation and purpose of middle and old } \\
\text { age counseling volunteers' participation in } \\
\text { Keelung Lifeline. } \\
\text { 2. Self-awareness is inspired by experiential } \\
\text { learning. } \\
\text { 3. Middle and old age counseling volunteers } \\
\text { gradually transform to seek a secure } \\
\text { attachment status during experiential } \\
\text { learning. }\end{array}$ \\
\hline $\begin{array}{c}\text { Ching-min Ma } \\
{[16]}\end{array}$ & $\begin{array}{l}\text { Social Participation of the } \\
\text { Elderly, Factors for } \\
\text { Consideration, and Benefits of } \\
\text { the Activities }\end{array}$ & $\begin{array}{l}\text { 1. The elderly who participated in the sites } \\
\text { were mainly female senior citizens, and } \\
\text { the types of social participation were } \\
\text { mainly club activities and leisure } \\
\text { activities. } \\
\text { 2. The ability factor was the highest factor } \\
\text { for consideration, while the resource factor } \\
\text { was the lowest in determining the } \\
\text { participation of the elderly in activities. } \\
\text { 3. Gender, education level, and personal } \\
\text { health status showed significant } \\
\text { differences in the benefits of the elderly's } \\
\text { activities. } \\
\text { 4. The type of social participation and the } \\
\text { factors of willingness, ability, and } \\
\text { resources were all highly correlated with } \\
\text { the benefits of the activities. }\end{array}$ \\
\hline
\end{tabular}

Note: Compiled by this study 


\subsection{The Motivation of the Elderly to Participate in Social Services and Related Theories}

A. Motivation is one of the most complex psychological traits of human beings. Motivation refers to the inner process that leads individuals to perform various activities, continue activities that have been started, and drive the activities toward a focused goal. The motivation of social service is discussed from the following theoretical perspectives, as shown in Table 2.

Table 2: Motivation-related Theories

\begin{tabular}{|c|c|c|}
\hline Scholars & Theory & Research Result \\
\hline Abraham Maslow [17] & $\begin{array}{l}\text { Maslow's } \\
\text { Hierarchy of } \\
\text { Needs }\end{array}$ & $\begin{array}{l}\text { According to the pyramid structure, from the } \\
\text { lowest to the highest level, the hierarchy of needs } \\
\text { is as follows: (1) Physiological, (2) Safety, (3) } \\
\text { Love/Belonging, (4) Esteem, and (5) Self- } \\
\text { actualization. }\end{array}$ \\
\hline Thomas Nagel [18] & Altruism & $\begin{array}{l}\text { The willingness to consider for the benefit of } \\
\text { others does not necessarily require self-sacrifice } \\
\text { on the part of the individual; altruism can also be } \\
\text { the act of satisfying one's own needs while } \\
\text { satisfying the needs of others, without expecting } \\
\text { to receive anything in return. }\end{array}$ \\
\hline Victor H. Vroom [19] & $\begin{array}{c}\text { Expectancy } \\
\text { Theory }\end{array}$ & $\begin{array}{l}\text { Human behavior is a goal-oriented, rational } \\
\text { process of conscious choice, and people expect to } \\
\text { achieve the desired outcome behind the behavior. } \\
\text { This outcome is attractive to the individual and is } \\
\text { influenced by value preferences and the drive of } \\
\text { whether the outcome can satisfy the needs. }\end{array}$ \\
\hline Albert Bandura [20] & $\begin{array}{l}\text { Self- } \\
\text { Efficacy } \\
\text { Theory }\end{array}$ & $\begin{array}{l}\text { When faced with a challenging job, individuals } \\
\text { evaluate the nature of the job and their own } \\
\text { abilities to determine the level of motivation in } \\
\text { accepting the challenge. }\end{array}$ \\
\hline Havighurst [21] & $\begin{array}{l}\text { Activity } \\
\text { Theory }\end{array}$ & $\begin{array}{l}\text { Activity participation helps the elderly identify } \\
\text { their own roles, which in turn replaces their lost } \\
\text { social roles and allows them to maintain good } \\
\text { social adaptation. }\end{array}$ \\
\hline Atchley [3] & $\begin{array}{c}\text { Continuity } \\
\text { Theory }\end{array}$ & $\begin{array}{l}\text { The stages of the human life cycle are } \\
\text { progressive, and the integration of the previous } \\
\text { stages helps individuals develop adaptation } \\
\text { strategies for the next stage. }\end{array}$ \\
\hline Cavan [22] & $\begin{array}{c}\text { Social } \\
\text { Participation } \\
\text { Theory }\end{array}$ & $\begin{array}{l}\text { Elder persons have the same psychological and } \\
\text { social needs for activity as the middle aged. Most } \\
\text { seniors do not want to lose their social role and } \\
\text { can still work and participate in social activities. }\end{array}$ \\
\hline
\end{tabular}


Maslow believes that human needs are distributed in a pyramidal pattern and that if one need is satisfied, that need is no longer a motivating factor and will be replaced by another, more elevated need.

The most immediate perception of social services by the general public is "doing a good deed," which in psychological research can be called an "altruistic behavior" or "prosocial behavior." People who help others, do so voluntarily; they are motivated by personal moral sentiments or social ethics rather than on the basis of agreed responsibilities or obligations.

The basic premise of the expectancy theory, also known as the means theory, is that motivation comprises a combination of the intensity of an individual's expectations and their personal values. The point of this theory is that social service workers' motivation to engage in service is highly related to personal expectations, personal beliefs, and values.

Self-efficacy is an individual's assessment of their own ability level, while actionoutcome expectation is a judgment of the possible outcome of this behavior. For example, believing that one can finish a 40-km marathon in 3 hours is a self-efficacy judgment, while anticipating the praise, ranking, and self-satisfaction that this behavior will bring is an action-outcome expectation.

According to the activity theory, elderly people are more likely to volunteer in order to maintain their self-identity and to replace their lost social roles [23].

The continuity theory suggests that people tend to maintain stability in their preferences, attitudes, and behaviors and that those who volunteered when they were young will have higher willingness to participate in the activity when they are older [23].

The social participation theory has important social significance. In the past, the government's welfare benefits for senior citizens traditionally focused on residential policies, health care, home services, and the enhancement of the living environment for the elderly. However, as the demographic characteristics of the elderly change and their needs change, social participation and educational and cultural services for the elderly are gradually being extended.

B. Summarizing the above seven theories, we can see that the motivation of the elderly to participate in social services may be different. However, there are no studies yet on the motivation of the elderly without a volunteer card who participate in social services in Taiwan. The motivation for social services and the drive for continued participation are the directions in which we would like to research further. Therefore, the researcher worked with eight senior citizens from his life circle and interviewed them to study their motivation, feeling, and experience of social services through the factors of motivation-related theories 


\section{Research Method}

An "in-depth interview" is an activity wherein the researcher "inquires about" and "interviews" the researched person and holds "a conversation" and conducts "inquiries" with them. An in-depth interview is a type of research conversation wherein the researcher collects (or "constructs") first-hand information from the subject through oral conversations, where both parties jointly construct "facts" and "behaviors" through the process of interaction [24]. This study adopts a "semistructured" in-depth interview method.

\subsection{Analysis of the Interviewees}

This study was conducted with eight senior citizens aged 65 years or older through one-on-one interviews. Prior to the interview, the researcher obtained consent from the interviewees to record the interview and take notes to ensure the completeness and accuracy of the interview content. This study conducted in-depth interviews with the interviewees and was also open to ad-hoc questions and discussions, and the duration of the interview varied depending on the situation on site.

After the interviews were completed, the interview content was organized and analyzed according to the field notes and recordings, and every detail of the interview was documented in the verbatim transcript, including the name of the interviewee, time and place, the researcher's questions and instructions, and the interviewee's responses and opinions. Table 3 contains the analysis of the interviewees.

Table 3: Analysis of the Interviewees

\begin{tabular}{|c|c|c|c|c|c|c|}
\hline $\begin{array}{c}\text { Pre-retirement } \\
\text { Career }\end{array}$ & Job Title & $\begin{array}{c}\text { Years of } \\
\text { volunteering } \\
\text { (including pre-work) }\end{array}$ & Age & Gender & $\begin{array}{c}\text { Education } \\
\text { Level }\end{array}$ & Code \\
\hline $\begin{array}{c}\text { Yixing } \\
\text { Electronics }\end{array}$ & $\begin{array}{c}\text { Deputy } \\
\text { General } \\
\text { Manager }\end{array}$ & 11 years & 72 & Male & Master's & A \\
\hline $\begin{array}{c}\text { Fu Tai Shiang } \\
\text { Enterprise }\end{array}$ & Director & 15 years & 69 & Male & University & B \\
\hline $\begin{array}{c}\text { Banqiao Senior } \\
\text { High School }\end{array}$ & $\begin{array}{c}\text { Team } \\
\text { Leader }\end{array}$ & 18 years & 68 & Female & University & C \\
\hline $\begin{array}{c}\text { Taoyuan Police } \\
\text { Department }\end{array}$ & $\begin{array}{c}\text { Team } \\
\text { Leader }\end{array}$ & 4 years & 69 & Male & University & D \\
\hline $\begin{array}{c}\text { Chunghwa } \\
\text { Telecom }\end{array}$ & Manager & 3 years & 70 & Male & University & E \\
\hline Hospital & Nurse & 43 years & 66 & Female & $\begin{array}{c}\text { Senior High } \\
\text { School }\end{array}$ & F \\
\hline $\begin{array}{c}\text { Former (Police) } \\
\text { Household } \\
\text { Administration }\end{array}$ & Employee & 25 years & 80 & Female & $\begin{array}{c}\text { Senior High } \\
\text { School }\end{array}$ & G \\
\hline Career & Nanny & 22 years & 81 & Female & $\begin{array}{c}\text { Junior High } \\
\text { School }\end{array}$ & H \\
\hline
\end{tabular}




\subsection{Data Analysis Methods}

This study adopts concepts from many motivation theories in the literature as its main research structure and explores the influence of factors related to the elderly's engagement in social services. In this research, nine-question variants were designed, and semi-structured in-depth interviews were conducted. The respondents provided answers based on their perceptions of engagement in social services, and post-interview data were also analyzed verbatim to form themes and extract meaning. The interview themes are shown in Table 4.

Table 4: Interview Themes

\begin{tabular}{|c|c|c|c|}
\hline No. & Name of Theory & $\begin{array}{c}\text { Variable } \\
\text { Definitions }\end{array}$ & Interview Questions \\
\hline 1 & $\begin{array}{l}\text { Hierarchy of } \\
\text { needs }\end{array}$ & $\begin{array}{l}\text { Influencing } \\
\text { Factors }\end{array}$ & $\begin{array}{c}\text { How long have you been working in } \\
\text { social services since you retired? What } \\
\text { are your reasons for choosing social } \\
\text { services? }\end{array}$ \\
\hline 2 & $\begin{array}{l}\text { Self-efficacy } \\
\text { theory and Social } \\
\text { Participation } \\
\text { Theory }\end{array}$ & $\begin{array}{l}\text { Influencing } \\
\text { Factors }\end{array}$ & $\begin{array}{c}\text { What are your motivations for } \\
\text { participating in social services? (from } \\
\text { mobile apps, Facebook, Line, or friends' } \\
\text { introduction). Is it related to your } \\
\text { previous profession? }\end{array}$ \\
\hline 3 & Altruism & $\begin{array}{l}\text { Influencing } \\
\text { Factors }\end{array}$ & $\begin{array}{c}\text { What are your reasons for participating } \\
\text { in social services without getting a } \\
\text { volunteer card? }\end{array}$ \\
\hline 4 & $\begin{array}{c}\text { Social } \\
\text { Participation and } \\
\text { Expectancy } \\
\text { Theory }\end{array}$ & $\begin{array}{l}\text { Motivation } \\
\text { and } \\
\text { Difficulties }\end{array}$ & $\begin{array}{c}\text { What is the sense of significance of your } \\
\text { service work, or what are the factors that } \\
\text { make you want to continue? }\end{array}$ \\
\hline 5 & $\begin{array}{l}\text { Expectancy } \\
\text { Theory }\end{array}$ & $\begin{array}{l}\text { Motivation } \\
\text { and } \\
\text { Difficulties }\end{array}$ & $\begin{array}{c}\text { How do your family and friends feel } \\
\text { about your involvement in social service } \\
\text { work? }\end{array}$ \\
\hline 6 & Activity Theory & $\begin{array}{l}\text { Motivation } \\
\text { and } \\
\text { Difficulties }\end{array}$ & $\begin{array}{l}\text { What services and help does your work } \\
\text { provide? Do you have any memorable or } \\
\text { heartwarming experiences? }\end{array}$ \\
\hline 7 & Activity Theory & $\begin{array}{c}\text { Changes } \\
\text { Before and } \\
\text { After }\end{array}$ & $\begin{array}{l}\text { Do you feel a change in your perception } \\
\text { toward yourself? What are the changes? }\end{array}$ \\
\hline 8 & $\begin{array}{l}\text { Continuity } \\
\text { Theory }\end{array}$ & $\begin{array}{c}\text { Changes } \\
\text { Before and } \\
\text { After }\end{array}$ & $\begin{array}{l}\text { Did you participate in social services } \\
\text { before working? }\end{array}$ \\
\hline 9 & $\begin{array}{l}\text { Continuity } \\
\text { Theory }\end{array}$ & $\begin{array}{l}\text { Changes } \\
\text { Before and } \\
\text { After }\end{array}$ & $\begin{array}{l}\text { What growth have you experienced } \\
\text { since you joined social services? (What } \\
\text { did you learn? What are the benefits? } \\
\text { How did you change after your service?) }\end{array}$ \\
\hline
\end{tabular}

Source: Compiled by this study 


\section{Research Results}

The researcher interviewed eight elderly people who did not have a volunteer card. The study used three variables to define the motivating and influencing factors of social service, which are "the relationship between the personal background and the factors of consideration and benefits of performing social services," "motivation and difficulties in engaging in social services," and "changes after participating in social services."

\subsection{The Relationship Between Personal Background and the Factors of Consideration and Benefits of Performing Social Services}

First, regarding the basic information of the interviewees, among the eight participants, four were male and four were female. The participants are divided into three categories according to their profession before retirement: $\mathrm{A}, \mathrm{B}$, and $\mathrm{E}$ were private company employees; $\mathrm{C}$ and $\mathrm{D}$ were public servants; and $\mathrm{F}, \mathrm{G}$, and $\mathrm{H}$ were general service workers. Four interviewees were aged 65-69, two were aged 70-79, and two were aged 80-85. The years of experience of the interviewees in social services (including before their retirement) are two interviewees with 1-5 years, three with 10 years or more, and another three with 20 years or more.

From the "hierarchy of needs" theory, we can observe the motivation of the elderly to engage in social services. Three of them, A, D, and E, were motivated to serve the society after retirement. A did not have a plan for retirement but wanted to find something to pass time due to his psychological needs. Before retirement, he noticed that there was a Tzu Chi Recycling and Blessing Station near his home. What originally was just an activity to pass time became a continuous engagement for him as his values changed. D and E approached the schools themselves to ask if they could volunteer there.

Five of them, B, C, F, G, and H, were already engaged in social services before their retirement. $\mathrm{B}$ had helped to care for the neighbors before retirement, such as by sending help to the poor families in the neighborhood, and continued to engage in such services for three years after retirement without taking a break. In the case of $\mathrm{F}$, who had been engaged in the Tzu Chi police services for 43 years, her motivation came from her late husband. Her husband was a police officer and was in bad health throughout the five years before his retirement. As a staff member in the hospital herself, $\mathrm{F}$ felt the hardships police officers faced and, therefore, was motivated to serve the police. She would care for the officers' wellness, monitor their blood pressure, and cook Chinese food for them at the police station. It made her feel close to her husband every day, and she felt fulfilled with the joy of Dharma. This was quite a special social service. As for $G$, she was very enthusiastic and spared no effort to serve others without asking for anything in return. This enthusiasm and spirit in helping others continued after her retirement where she was able to shine to the fullest in social services.

The motivational factors influencing the eight interviewed seniors to serve the society from the "hierarchy of needs theory" are summarized in Table 5. 
Table 5: Motivational Factors of the Elderly Interviewees in Serving the Society

\begin{tabular}{|c|c|c|c|}
\hline Code & $\begin{array}{l}\text { Engaged in Social } \\
\text { Services Before } \\
\text { Retirement }\end{array}$ & $\begin{array}{l}\text { Pyramid Level in } \\
\text { the Hierarchy of } \\
\text { Needs Theory }\end{array}$ & $\begin{array}{c}\text { Influencing Motivation (Extracted } \\
\text { Significance). }\end{array}$ \\
\hline A & No & Physiological needs & $\begin{array}{l}\text { Make a living to meet "physiological } \\
\text { needs." }\end{array}$ \\
\hline B & Yes & $\begin{array}{l}\text { Self-actualization } \\
\text { needs }\end{array}$ & $\begin{array}{l}\text { Drawing out the best from others through } \\
\text { their own effort, being a person who cares } \\
\text { for people in extreme difficulty and those } \\
\text { who need help, helping others from the } \\
\text { heart, and making donations. }\end{array}$ \\
\hline $\mathrm{C}$ & Yes & $\begin{array}{l}\text { Self- actualization } \\
\text { needs }\end{array}$ & $\begin{array}{l}\text { It is more of a practice for self-cultivation; } \\
\text { participating in social services for the } \\
\text { public good and helping people in need is } \\
\text { an act of compassion. }\end{array}$ \\
\hline $\mathrm{D}$ & No & $\begin{array}{l}\text { Self- actualization } \\
\text { needs }\end{array}$ & $\begin{array}{l}\text { Inspired to contribute to society after } \\
\text { seeing people in strained circumstances; } \\
\text { felt joy by indulging in more social work. }\end{array}$ \\
\hline $\mathrm{E}$ & No & $\begin{array}{l}\text { Love/Belonging } \\
\text { needs }\end{array}$ & $\begin{array}{l}\text { Afraid of having no friends after retirement } \\
\text { and thus joined social service. }\end{array}$ \\
\hline $\mathrm{F}$ & Yes & $\begin{array}{l}\text { Self-actualization } \\
\text { needs }\end{array}$ & $\begin{array}{l}\text { To serve society well for the sake of her } \\
\text { late husband and for herself as well. It is } \\
\text { more joyful to give than to receive: "The } \\
\text { helper should help those who have no way } \\
\text { out in an emergency." }\end{array}$ \\
\hline $\mathrm{G}$ & Yes & $\begin{array}{l}\text { Self- actualization } \\
\text { needs }\end{array}$ & $\begin{array}{l}\text { After a lifetime of commuting by bicycle, } \\
\text { they often see situations that greatly } \\
\text { needed assistance. People, issues, and } \\
\text { things should all be helped to the best } \\
\text { effort. "Love knows no bounds"; we } \\
\text { should open our arms to serve people. "It } \\
\text { is more joyful to give than to receive." }\end{array}$ \\
\hline $\mathrm{H}$ & Yes & $\begin{array}{l}\text { Love/Belonging } \\
\text { and physiological } \\
\text { needs }\end{array}$ & $\begin{array}{l}\text { We should honor and help the elderly and } \\
\text { the young in other families as we honor and } \\
\text { help those in our own. I feel happy to be } \\
\text { able to help society in my own way. I am } \\
\text { encouraged by the teachers and students } \\
\text { when I volunteer at the school and feel very } \\
\text { pleased. }\end{array}$ \\
\hline
\end{tabular}


In terms of the "self-efficacy theory" and "social participation theory," A, who works at Tzu Chi Recycling Station, found that his professional knowledge could be put to good use as he knew which items, such as plastic and electrical appliances, could be recycled, decomposed, or utilized. B is self-motivated to serve and said, "It is more blessed to serve others than to be served." The other six believe that as they are still physically able, as long as they can walk, they should serve society without fail.

"Altruism" is the reason the eight interviewees in this study did not want to obtain the volunteer card. More details are shown in Table 6.

Table 6: Reasons for Not Wanting to Obtain a Volunteer Card

\begin{tabular}{|c|c|}
\hline Code & Reason \\
\hline $\mathrm{A}$ & $\begin{array}{l}\text { Why do I need a volunteer card? It requires a number of service } \\
\text { hours; it is too much trouble. I serve when I want to. }\end{array}$ \\
\hline $\mathrm{B}$ & $\begin{array}{l}\text { It is more rewarding to serve than to be served. It is not necessary to } \\
\text { have a volunteer card or to be certified to perform social service. }\end{array}$ \\
\hline $\mathrm{C}$ & $\begin{array}{l}\text { I know that some social services require people to be a member of } \\
\text { the organization in order to serve. I think that the value of social } \\
\text { services is lost like this. It is as if we are giving back to society for } \\
\text { the hours. }\end{array}$ \\
\hline $\mathrm{D}$ & $\begin{array}{l}\text { Retirement is not about fame and fortune but about serving people } \\
\text { while you are still physically fit. I don't need to get a volunteer card } \\
\text { and enjoy the benefits. }\end{array}$ \\
\hline $\mathrm{E}$ & $\begin{array}{l}\text { I want to be happy doing the services. A set number of service hours } \\
\text { is required to get a volunteer card; I want more freedom. }\end{array}$ \\
\hline $\mathrm{F}$ & I do not want to be constrained. \\
\hline $\mathrm{G}$ & $\begin{array}{l}\text { I am giving love with all my heart and doing social service } \\
\text { whenever, wherever I am. I don't need hours to prove my service. }\end{array}$ \\
\hline $\mathrm{H}$ & $\begin{array}{l}\text { I do not need a certificate to prove my good intentions in serving } \\
\text { society. }\end{array}$ \\
\hline
\end{tabular}

\subsection{Motivation and Difficulties in Engaging in Social Service}

From the perspective of the social participation theory, expectancy theory, and activity theory, the family members of the eight interviewees are all in favor of social services. A chose the Tzu Chi Recycling Station, but at that time, he did not know what Tzu Chi does, only that there was something to do at this place. He later found out that he could put his knowledge gained from his previous profession into use, such as how to decompose and reuse electrical appliances and plastics. People would consult A about this. A also knows how to recycle these products and transform them into new things and then donate them to those in need. Not only did A help Tzu Chi Recycling Station earn a lot of money (through donations), but he also educated others. He taught what he learned before to a group of elderly around 
his age and mentioned that he would continue doing these social services until the day he cannot move. A said he had left behind who he was in the past and making a small contribution to the planet is highly satisfying. When B talked about serving the society, he mentioned that typically speaking, people would hesitate and be unwilling to contribute as there is no organization or funding. However, B has a sense of gratitude and appreciation in him, an attitude that is derived from B's parents, who taught him to always be grateful and that it is an honor to serve society. $\mathrm{C}$ was motivated by her aunt's daughter, who does not have a high income but still does charity and perform social services. C saw that even though the sofa in her house was in tatters, she did not bother to fix it but would donate part of her income. $\mathrm{C}$ was inspired by her and decided to participate in social services. D is a traffic warden at a school as he was a traffic police officer. He is very glad that he is able to get the children to school safely, educate and guide them on the positive effects of being grateful, and knows difficulties of grandfathers. F volunteers in Tzu Chi police services; she cares for the hard-working police officers on the frontlines, monitors their blood pressure, pays attention to their health, and prepares vegetarian food for them to eat at lunchtime. F feels closer to her late husband when taking care of them. G works in caregiving services where "love" is the essence; her "profession" was to take care of critically ill patients, which allowed her to grow from the experience. "It is a matter of life and death; be bold but cautious." As a caregiver who has taken care of several critically ill patients, $G$ enjoys serving even with the hardships. G said that she is no superhuman but that she knows how to break through all the difficulties with love and professionalism. With love, one can make up for innate weaknesses. Temporary bliss can also make one very happy. E and $\mathrm{H}$ had no heartwarming stories; they just feel happy working with other seniors in serving people and receiving appreciation from the teachers and students.

The social participation theory, expectancy theory, and activity theory are the purpose and motivating factors of social service participation for the eight interviewees in this study. More details are shown in Table 7. 
Table 7: Purpose and Motivating Factors of Social Service Participation

\begin{tabular}{|c|c|c|c|}
\hline Code & Theory & Motivation & $\begin{array}{c}\text { Motivating Factors } \\
\text { (Extracted Significance) }\end{array}$ \\
\hline A & $\begin{array}{c}\text { Expectancy and } \\
\text { Social Participation } \\
\text { Theory }\end{array}$ & $\begin{array}{l}\text { Environmental protection and } \\
\text { recycling can make a small } \\
\text { contribution to the planet. }\end{array}$ & $\begin{array}{l}\text { Personal values in helping } \\
\text { society }\end{array}$ \\
\hline B & Expectancy Theory & $\begin{array}{c}\text { Since childhood, his parents have } \\
\text { taught him to always be grateful } \\
\text { and that it is an honor to serve } \\
\text { society. }\end{array}$ & $\begin{array}{l}\text { Feels incumbent to show } \\
\text { love and not lose to } \\
\text { anyone in showing love. } \\
\text { Does not expect rewards }\end{array}$ \\
\hline $\mathrm{C}$ & $\begin{array}{l}\text { Activity and Social } \\
\text { Participation Theory }\end{array}$ & $\begin{array}{l}\text { After seeing someone poorer than } \\
\text { herself sacrificing the pleasures } \\
\text { they deserve, she was determined } \\
\text { to serve society as well. }\end{array}$ & $\begin{array}{c}\text { The heartwarming } \\
\text { experience motivated her } \\
\text { to engage in social } \\
\text { services }\end{array}$ \\
\hline $\mathrm{D}$ & Expectancy Theory & $\begin{array}{l}\text { Having a positive impact on the } \\
\text { children as they are taught to be } \\
\text { grateful and to learn about the hard } \\
\text { work of their grandparents; being } \\
\text { recognized by the teachers and } \\
\text { parents }\end{array}$ & $\begin{array}{l}\text { Happy to do so and } \\
\text { willing to take on the } \\
\text { responsibility }\end{array}$ \\
\hline $\mathrm{E}$ & Activity Theory & $\begin{array}{l}\text { Serving as a school traffic warden } \\
\text { and providing cleaning service; } \\
\text { meeting new friends and finding } \\
\text { new life experiences }\end{array}$ & $\begin{array}{l}\text { Replacing the lost original } \\
\text { social role }\end{array}$ \\
\hline $\mathrm{F}$ & Expectancy Theory & $\begin{array}{l}\text { Serving at the police station is like } \\
\text { working with her deceased } \\
\text { husband, which provides a sense of } \\
\text { completion. }\end{array}$ & Fulfilling the need \\
\hline G & Expectancy Theory & $\begin{array}{c}\text { She used to meddle in a lot of } \\
\text { matters when she was working, and } \\
\text { she would help whenever she saw } \\
\text { someone pitiful or a colleague in } \\
\text { trouble. }\end{array}$ & $\begin{array}{c}\text { Short-term bliss is also } \\
\text { enjoyable }\end{array}$ \\
\hline $\mathrm{H}$ & Activity Theory & $\begin{array}{l}\text { She volunteers to help clean up the } \\
\text { campuses of junior high and } \\
\text { elementary schools. When the } \\
\text { students call her "grandma" and } \\
\text { thank her for the hard work, it is all } \\
\text { worth it. }\end{array}$ & $\begin{array}{l}\text { Replacing the lost original } \\
\text { social role }\end{array}$ \\
\hline
\end{tabular}




\subsection{Changes Before and After Being Engaged in Social Services}

From the perspective of the continuity theory and activity theory, A was very busy when he was working before retirement and did not think of serving the society, while $\mathrm{D}$ and $\mathrm{E}$ planned to serve people after retiring. According to the continuity theory, B, C, F, G, and $\mathrm{H}$ had participated in social services while they were working and had a higher willingness to participate in volunteer services after retirement. The perceptions of the eight interviewees after conducting social services are shown in Table 8.

Table 8: Concepts and Recommendations after Serving the Society

\begin{tabular}{|c|c|}
\hline Code & Concepts and Recommendations \\
\hline $\mathbf{A}$ & $\begin{array}{l}\text { Those who are } 70 \text { or } 80 \text { years old like me but are still working } \\
\text { actively in their companies are rich but do not have a life; they are } \\
\text { very jealous of my life right now. I learned not to waste any time; I } \\
\text { did not want to retire at home and wait for death. I wanted to do } \\
\text { something for society. I was able to live well because of what was } \\
\text { taken from the society, and now it is time to give back. }\end{array}$ \\
\hline B & $\begin{array}{l}\text { I think it is worthwhile for young people to participate in social } \\
\text { services and contribute more. Serving without expecting anything } \\
\text { in return can teach them a lot about life. }\end{array}$ \\
\hline $\mathbf{C}$ & $\begin{array}{l}\text { It is a joy to serve society, and through serving society, we } \\
\text { accumulate our own blessings and fortune. I hope retired seniors } \\
\text { can make good use of the years they have left to live, go out to } \\
\text { contribute to society if they can, and give as much as they can. }\end{array}$ \\
\hline $\mathbf{D}$ & $\begin{array}{l}\text { Give more if you have the ability; you will be able to bring positive } \\
\text { energy to social services. }\end{array}$ \\
\hline $\mathbf{E}$ & Do more for charity and serve people while you can still move. \\
\hline $\mathbf{F}$ & Don't spend your life in vain; learn more in your limited time. \\
\hline $\mathbf{G}$ & $\begin{array}{l}\text { Helping others is the most enjoyable activity as love knows no } \\
\text { bounds. In the face of people, things, and objects, we should "show } \\
\text { the spirit of love to the fullest." "It is more joyful to give than to } \\
\text { receive." I believe that society will be better if everyone shows their } \\
\text { warmth to others. }\end{array}$ \\
\hline $\mathbf{H}$ & $\begin{array}{l}\text { I don't have a high education level. I think we should take one step } \\
\text { at a time to plant love deeply. }\end{array}$ \\
\hline
\end{tabular}

\section{Conclusion and Recommendations}

Based on the analysis results of this study, the conclusions and specific recommendations are summarized as follows. First, this study reveals that among the elderly who were engaged in social services after their retirement, three made propositions in regard to the management and technical aspects for the groups or units where they work. They believe that it is not easy to be a social service worker, 
and they must be connected to a local service for proper management and technical support. All three of them were able to put their knowledge from their past profession to good use in the group they were serving with and pointed out that there is no high or low level of service but that there should be a leader to teach them. They all realized that they should swallow their pride when engaging in social services after retirement, as there is no point in being proud.

From the interview data regarding what influenced the eight people to participate in social services, we learned that, except for the three seniors mentioned above who engaged in social services only after they retired, the other five had already used their free time to serve the society before retirement, and all five of them had their own causal stories that motivated them to serve with great love. In addition, in terms of the difficulties in social services encountered by the eight interviewees, four of them pointed out that, at certain charities and groups, some people that do have a volunteer card would be stingy and reject to donate when there is a need to make a donation to help others. These people are in membership-based charity groups that have funds; however, when the funds are insufficient, they would have to raise money using their own resources. However, since the eight elderly people interviewed in this study are performing selfless and unpaid social services and do not have a volunteer card, they are simply helping people in need out of their own pockets. This is something they can only do as much their ability allows, and it does not necessarily mean that other elderly people like them are all selfless and loving. Finally, in terms of the changes before and after engaging in social services, it is found that engagement in social services has a positive effect on the contentment of the elderly. They feel happier and more satisfied with their life after participating in social services.

For the elderly themselves, this study found that the more frequently the elderly over 65 years old participate in social services, the happier and more satisfied they will be with their lives. In view of this, it is recommended that the elderly themselves should recognize the importance of participating in social services and take an active role in the activity in order to enhance their life satisfaction in their later years. Certainly, the motivation of each elderly person varies greatly, and there are many possibilities that one may not be able to continue to participate in their preferred social services, but there are people in need of help everywhere in this society, and as long as the elderly can be motivated to participate in social services, they can undoubtedly bring a soft power to the society as they pass their accumulated experience onto others. 


\section{References}

[1] Monthly Statistical Report of the Ministry of the Interior, webpage: https://ws.moi.gov.tw/001/Upload/400/relfile/0/4413/1ef09c4c-ef0e-4035afdb-ea8fec457491/month/month.html.

[2] Chambré, S. M. (1993). "Volunteerism by elders: Past trends and future prospects." The Gerontologist, vol. 33, no. 2, 1993, pp. 221-229.

[3] Atchley, R. C. (1971). "Retirement and leisure participation: Continuity or crisis?." The Gerontologist, vol. 11, no. 1_Part_1, 1971, pp. 13-17.

[4] Turner, M. J. (1989). "Factors influencing attitude toward retirement and retirement planning among midlife university employees." Doctoral dissertation, Texas Tech University, 1989.

[5] Mitchell, T. R. (1973). "Motivation and participation: An integration." Academy of Management Journal, vol. 16, no. 4, 1973, pp. 670-679.

[6] Townsend, B. G., Chen, J. T. and Wuthrich, V. M. (2021). "Barriers and facilitators to social participation in older adults: A systematic literature review." Clinical Gerontologist, 2021, pp. 1-22.

[7] Chen, Y. (2007). "Retirement elementary school retires a teacher's society to participate and the related quality of life study." Institute for the Education of the Elderly, National Chung Cheng University, 2007.

[8] Tzeng, S. (2015). "Digital engagement and social inclusion: Past and future." Journal of Cyber Culture and Information Society, no. 29, 2015, pp. 1-26.

[9] Lin, M. (2021). "Influencing factors of social service satisfaction of the elderly under the background of internet attention." DOI:10.1155/2021/9985280, 2021.

[10] Kai, S. (2021). "Does social participation improve cognitive abilities of the elderly?.” Journal of Population Economics, 2021, pp. 1-29.

[11] Zhang, Y., Li, W. and Wang, L. (2021). "Design of elderly care service in rural community with mutual assistance mode-A case study of B rural community in A town, Beijing." International Conference on Human-Computer Interaction, July 2021, pp. 318-326.

[12] Wanchai, A. and Phrompayak, D. (2019). "Social participation types and benefits on health outcomes for elder people: A systematic review." Ageing International, vol. 44, no. 3, 2019, pp. 223-233.

[13] Zhang, G., Zheng, Q., Jingjing, W. U., Zheng, Q. and Decong, T. A. N. G. (2020). "A study on the correlations among elder volunteers' participation motivation, happiness, and intention of continuous participation." Revista de Cercetare si Interventie Sociala, vol. 68, 2020.

[14] Lee, M. (2021). "The relationship between the participation attitude and selfefficacy among the elder volunteers." Master's Thesis, Department of Adult and Continuing Education, National Chung Cheng University, 2021.

[15] Lee, H. (2021). "Discussion on experience learning and reflexivity practice of counseling volunteers for middle and old age. The case study of Keelung lifeline." Master's Thesis, Program of Family Services for the Aged, 
Department of Family Studies and Child Development, Shih Chien University Taipei Campus, 2021.

[16] Ma, C. (2021). "Elderly people's social participation, influencing factors and benefits of activity." Master's Thesis, Department of Social Work, Tunghai University, 2021.

[17] Maslow, A. (1943). "Maslow's hierarchy of needs." Index of DOCS/Teaching \{sp\} Collection/Honolulu, 1943.

[18] Nagel, T. (1962). "The possibility of altruism." Princeton University Press, 1978.

[19] Vroom, V.H. (1962)."Ego involvement, job satisfaction, and job performance.” Personnel Psychology, 1962.

[20] Bandura, A. (1982). "Self-efficacy mechanism in human agency." American Psychologist, vol. 37, no. 2, 1982, p. 122.

[21] Havighurst, R. J. (1963). "Successful aging," Processes of aging: Social and psychological perspectives, vol. 1, 1963, pp. 299-320.

[22] Cavan, R. S. (1953). "MACE. Hebrew marriage: A sociological study (Book review)," Social Forces, vol. 32, no. 1, 1953, p. 393.

[23] Utz, R. L., Carr, D., Nesse, R. and Wortman, C. B. (2002). "The effect of widowhood on older adults' social participation: An evaluation of activity, disengagement, and continuity theories." The Gerontologist, vol. 42, no. 4, 2002, pp. 522-533.

[24] Chen, X. (2002). "The qualitative study of social science." Wu-Nan Book Inc, 2002. 